\author{
Marcin ZUBEK \\ Uniwersytet Jagielloński w Krakowie \\ marcin.zubek@uj.edu.pl
}

\title{
KONTESTACJA WSPÓLNEJ POLITYKI BEZPIECZEŃSTWA I OBRONY W PARLAMENCIE EUROPEJSKIM NA PRZYKŁADZIE DZIAŁAŃ UE W AFGANISTANIE W LATACH 2005-2013 ${ }^{1}$
}

ABSTRACT Contestation of the common foreign and security policy in European Parliament. The case of EU actions in Afghanistan in 2005-2013

Foreign policy, including the security policy, has traditionally been considered a domain of the public policy, where lower standards of parliamentary democratic control and scrutiny can be employed. There is a belief among the policy-makers, that in order to act effectively in this field, they should not be limited by the legislative power. This democratic deficit is even amplified on the international level, whenever an international organization is involved in implementing security policy. In spite of that fact, parliaments still retained the right to scrutinize security policies via debates, which reveal MPs approach towards state's security policy. The main aim of this article is to analyze a case of democratic control over security policy on the international level, namely the security policy towards Afghanistan between 2005 and 2013 and its contestation in the European Parliament (EP). In order to do so a qualitative analysis of the plenary debates in the EP will be employed, which will reveal arguments used by the MEPs in order to justify certain policies, political claims directed to national and

1 Badania prezentowane w artykule są częścią projektu badawczego Kontrola demokratyczna i legitymizacja Europejskiej Polityki Zagranicznej na przyktadzie polityki rozszerzenia UE i Europejskiej Polityki Sasiedztwa (nr 2012/05/D/HS5/01549) finansowanego z Narodowego Centrum Nauki, prowadzonego od 2013 r. w Instytucie Europeistyki na Uniwersytecie Jagiellońskim. 
international institutions and contestation of the process of the formulation of the EU policy towards this particular security issue.

Key words: Afghanistan, Foreign Policy, Common Security and Defence Policy, contestation, European Parliament

Słowa kluczowe: Afganistan, polityka zagraniczna, Wspólna Polityka Bezpieczeństwa i Obrony, kontestacja, Parlament Europejski

$\mathrm{P}$ olityka zagraniczna państwa, w tym także polityka bezpieczeństwa, tradycyjnie jest uważana za domenę, do której można stosować niższe standardy, jeśli chodzi o jej demokratyczną kontrolę i kontestację na poziomie parlamentarnym. Uważa się, że polityka ta, aby działać efektywnie, powinna cieszyć się większą dozą tajności, a decydenci powinni mieć większe pole manewru i być elastyczni w podejmowaniu decyzji, które nie będą uzależnione od aprobaty legislatywy². Taki swoisty „demokratyczny deficyt” jest jednak tylko częścią problemu, jeśli wziąć pod uwagę sytuację, kiedy polityka bezpieczeństwa prowadzona jest poprzez organizacje międzynarodowe, pod auspicjami których używana jest siła militarna. W takim wypadku mamy do czynienia z „podwójnym deficytem demokracji”, gdyż do niechęci do kontroli parlamentarnej na poziomie krajowym dołącza jeszcze brak instrumentów takiej kontroli na poziomie międzynarodowym. Co więcej, operacje militarne poza granicami państwa są przedsięwzięciem bardzo kontrowersyjnym politycznie i społecznie i gdy nie przebiegają zgodnie z planem i przynoszą dużo strat w ludziach, są bardzo mocno kontestowane, zarówno przez opinię publiczną, jak i na arenie politycznej. Za przykład mogą posłużyć masowe protesty w Wielkiej Brytanii przeciwko wojnie w Iraku ${ }^{4}$ czy badania opinii publicznej w Polsce podczas interwencji w Afganistanie 5 . Podobna sytuacja ma miejsce, gdy oprócz strat personelu operacje takie pociągają za sobą ogromne wydatki, a w przypadku operacji militarnych z dala od macierzy taki stan rzeczy jest regułą.

Nie oznacza to oczywiście, że parlamenty nie posiadają żadnej kontroli nad działaniami rządów w kwestiach bezpieczeństwa. Wiele zależy od porządku prawnokonstytucyjnego w poszczególnych krajach, jednak co do zasady można wyróżnić kilka mechanizmów, które sprawiają, że parlamenty mają bądź realny wpływ na kształt tej

2 W. Wagner, The democratic deficit in the EU's security and defense policy - why bother?, referat wygłoszony na EUSA Tenth Biennial International Conference Montreal, Canada, 17-19 V 2007, s. 2.

3 Termin ukuty przez: H. Hänggi, The use of force. Parliamentary accountability and „Democratic deficits”, [w:] H. Born, H. Hänggi, The „Double Democratic Deficit”. Parliamentary Accountability and the Use of Force Under International Auspices, Ashgate 2004, s. 6-7.

4 "Million” march against Iraq war, [online] http://news.bbc.co.uk/2/hi/2765041.stm, 18 VII 2017.

5 Zob. Udziat Polski w operacji NATO w Afganistanie i jego konsekwencje, Komunikat z badań CBOS, BS/159/2010. 
polityki, bądź też są o niej odpowiednio informowane, dzięki czemu sprawują nad nią nadzór. Mechanizmy te odzwierciedlają niektóre z funkcji parlamentów.

Tabela 1. Mechanizmy demokratycznej kontroli i nadzoru parlamentów nad operacjami militarnymi

\begin{tabular}{|c|c|}
\hline Funkcja & Mechanizmy \\
\hline Legislacyjna & $\begin{array}{l}\text { Możliwość przyjmowania aktów prawnych regulujących użycie sił zbrojnych } \\
\text { pod auspicjami organizacji międzynarodowych. }\end{array}$ \\
\hline Budżetowa & Zatwierdzanie budżetu operacji militarnych. \\
\hline Wyborcza & $\begin{array}{l}\text { Możliwość przegłosowania votum nieufności dla rządu, który podejmie de- } \\
\text { cyzję o interwencji militarnej. }\end{array}$ \\
\hline Reprezentacyjna & $\begin{array}{l}\text { Ułatwianie wypracowania konsensusu politycznego albo zgłaszanie niezadowo- } \\
\text { lenia w imieniu obywateli, gdy rząd podejmie decyzję o interwencji militarnej. }\end{array}$ \\
\hline Kontrolno-nadzorcza & $\begin{array}{l}\text { Prawo do informacji podczas prowadzonej interwencji (poprzez przesłucha- } \\
\text { nia, interpelacje, pytania, debaty, komisje śledcze, wizyty etc.). } \\
\text { Konsultowanie się z rządem przed interwencją (ale bez wiążącego głosu } \\
\text { w tej sprawie). } \\
\text { Współdecydowanie o interwencji. }\end{array}$ \\
\hline
\end{tabular}

Źródło: H. Hänggi, The use of force. Parliamentary accountability and „democratic deficits”, [w:] H. Born, H. Hänggi, The "Double Democratic Deficit”. Parliamentary Accountability and the Use of Force Under International Auspices, Ashgate 2004, s. 12.

Oprócz tych formalnych mechanizmów (authority), aby możliwe było sprawowanie takiej kontroli przez parlament, potrzebna jeszcze jest pewna zdolność administracyjna i biurokratyczna parlamentu jako całości (ability), a także zainteresowanych deputowanych. Zdolność taka wyraża się w dostępie do odpowiedniego zaplecza eksperckiego, co także faworyzuje rządy, z ich rozwiniętą siecią specjalistów oraz dostępem do ekspertyz tajnych. Należy jeszcze wspomnieć, że żadna należyta demokratyczna kontrola i nadzór nie będą sprawowane w przypadku, gdy deputowani nie będą wyrażać odpowiedniego zainteresowania kwestiami bezpieczeństwa (attitude) . Brak zainteresowania taką tematyką wcale nie dziwi, gdyż jest ona częstokroć daleka od spraw, które bezpośrednio dotyczą wyborców z okręgu danego parlamentarzysty (chyba że mamy do czynienia z jakimś spektakularnym medialnie wydarzeniem). Deputowany taki musi być w stanie przekonać tych, którzy będą głosować, że sprawy bezpieczeństwa związane z misjami militarnymi dotyczą bezpośrednio ich. Perswazja taka może się opierać na argumentacji o wpływie czynników zewnętrznych na ład wewnątrzpaństwowy poprzez np. ataki terrorystyczne czy problem niekontrolowanej migracji. Co więcej, opcja polityczna, która popiera rząd, może w ogóle nie być zainteresowana nadzorem nad działaniami egzekutywy, a opozycja może być zbyt słaba, żeby taką kontrolę efektywnie zainicjować

6 Rozróżnienie na te trzy elementy (authority, ability, attitude) wprowadzone przez: H. Hänggi, The use offorce..., s. 3-12.

7 Tamże, s. 13. 
W niniejszym artykule zajmę się tylko jedną z wyżej przytoczonych funkcji - mianowicie nadzorem i kontrolą sprawowaną za pomocą debat parlamentarnych. Celem tej pracy jest analiza żądań politycznych wysuwanych przez eurodeputowanych podczas dyskusji nad efektywnością operacji podtrzymywania pokoju, a konkretnie operacji międzynarodowej w Afganistanie (2001-2015). Dlatego też poniższa analiza nie będzie dotyczyć formalnoprawnych instrumentów kontroli tego aspektu polityki bezpieczeństwa, a skupi się na żądaniach politycznych i związanej z nimi kontestacji efektywności działań prowadzonych przez UE oraz społeczność międzynarodową w Afganistanie w latach 2005-2013. Co istotne, analiza będzie dotyczyć elementów związanych z efektywnością w działaniach na zewnątrz, ale bardzo ważnym jej elementem będzie też kontestacja samego procesu formułowania i używania instrumentów służących implementacji misji militarnych. Innymi słowy, działania rządów i organizacji międzynarodowych w ramach wszczynania i przeprowadzania misji militarnych kontestowane będą nie tylko w oparciu o ich ostateczny skutek, lecz także proces, jaki do tego skutku prowadzi.

Chodzi tutaj o problem ściśle związany z przedstawionym przez Roberta Dahla „dylematem demokracji”, który z jednej strony bierze pod uwagę możliwość wpływu obywateli (czy to bezpośrednio, czy to przez swoich przedstawicieli) na prowadzoną politykę, a z drugiej zdolność systemu do efektywnego działania w zaspokajaniu zbiorowych potrzeb obywateli ${ }^{8}$. Jest to zatem dylemat, który dotyczy oceny legitymizacji podejmowanych decyzji w oparciu o tzw. legitymizację wejściową (ang. input legitimacy), czyli związaną z demokratycznym procesem podejmowania decyzji (czasami stosuje się też anglojęzyczny termin process legitimacy), oraz legitymizację wyjściową (ang. output legitimacy), opierającą się na efektywności prowadzonych działań?

\section{PARLAMENT EUROPEJSKI - OGÓLNY ZARYS DEBAT}

Unia Europejska jest stosunkowo nowym aktorem, jeśli chodzi o międzynarodowe bezpieczeństwo i operacje pokojowe. Pomimo pewnego doświadczenia w misjach wojskowych i cywilnych ${ }^{10}$ zaangażowanie UE w rejonach objętych konfliktami zbrojnymi wciąż jest ograniczone, zarówno ze względu na liczebność personelu, jak i zakres wykonywanych zadań. Co więcej, rola Parlamentu Europejskiego, który jest jedynym prawdziwie demokratycznym organem przedstawicielskim UE, na forum którego mogą odbywać się debaty na temat unijnej polityki bezpieczeństwa, jest dość ograniczona i sprowadza się do opiniowania działań UE i zgłaszania pytań do odpowiednich organów władzy wykonawczej Unii, w tym przypadku do Komisji Europejskiej,

Zob. R.A. Dahl, A democratic dilemma. System effectiveness versus citizen participation, „Political Science Quarterly” 1994, Vol. 109, nr 1, s. 28, [online] https://doi.org/10.2307/2151659.

9 Zob. F.W. Scharpf, Governing in Europe. Effective and Democratic, Oxford 1999, s. 7.

10 Obecnie (stan na lipiec 2017) Unia Europejska prowadzi 6 operacji militarnych i 9 operacji cywilnych, a 18 operacji zostało zakończonych. 
a konkretnie do Wysokiego Przedstawiciela UE ds. Polityki Zagranicznej i Bezpieczeństwa, a także do innych komisarzy zajmujących się relacjami zewnętrznymi UE. Należy jednak nadmienić, że Parlament Europejski jest instytucją, która stopniowo, ale konsekwentnie walczy o dalsze prerogatywy w tej dziedzinie polityki. Niekiedy walka ta przynosi sukcesy - dobrym przykładem jest uzyskanie przez PE wglądu do tajnych i wrażliwych dokumentów Rady na podstawie Porozumienia międzyinstytucjonalnego z 2002 r. ${ }^{11}$, które de facto sprawiło, że PE miał dostęp do materiałów, którymi rządy państw członkowskich nie chciały się dzielić nawet ze swoimi parlamentami narodowymi ${ }^{12}$.

Te ograniczenia odzwierciedla fakt, że tematyka polityki Unii Europejskiej względem Afganistanu nie pojawia się często w debatach Parlamentu Europejskiego. W latach 2005-2013 w PE odbyło się łącznie 12 debat, w których kwestia afgańska była tematem głównym lub jednym z głównych (zob. tabela 2). Żadna z tych debat nie była poświęcona wyłącznie polityce UE w ramach Wspólnej Polityki Bezpieczeństwa i Obrony. Dyskusje przebiegały raczej na dwa sposoby - albo dotyczyły ogólnej polityki Unii względem Afganistanu, albo skupiały się na jednym, często bardzo wąskim aspekcie trwającego konfliktu.

Tabela 2. Debaty Parlamentu Europejskiego o Afganistanie

\begin{tabular}{|c|c|c|}
\hline Data & $\begin{array}{c}\text { Tytuł debaty } \\
\text { (w j. angielskim) }\end{array}$ & $\begin{array}{c}\text { Liczba } \\
\text { wypowiedzi }\end{array}$ \\
\hline $26 \times 2005$ & Afghanistan & 13 \\
\hline $24 \times 2007$ & Production of opium for medical purposes in Afghanistan & 16 \\
\hline 13 III 2008 & $\begin{array}{l}\text { Afghan journalist Perwiz Kambakhsh. The case of the Iranian citizen } \\
\text { Seyed Mehdi Kazemi }\end{array}$ & 15 \\
\hline 8 VII 2008 & $\begin{array}{l}\text { Stabilisation of Afghanistan: challenges for the EU and the interna- } \\
\text { tional community }\end{array}$ & 24 \\
\hline 24 IV 2009 & Women's rights in Afghanistan & 15 \\
\hline 24 XI 2009 & $\begin{array}{l}\text { Joint removals of irregular migrants to Afghanistan and other third } \\
\text { countries }\end{array}$ & 9 \\
\hline 16 XII 2009 & New EU action plan for Afghanistan and Pakistan & 34 \\
\hline 15 XII 2010 & A new strategy for Afghanistan & 36 \\
\hline 14 XII 2011 & Budgetary control of EU financial assistance to Afghanistan & 7 \\
\hline
\end{tabular}

11 Interinstitutional Agreement of 20 November 2002 between the European Parliament and the Council concerning access by the European Parliament to sensitive information of the Council in the field of security and defence policy, 2002/C 298/01, [online] http://eur-lex.europa.eu/legal-content/EN/TXT/ PDF/?uri=CELEX:32002Q1130(01)\&from=EN, 1 III 2016.

12 Zob. szerzej: G. Rosén, EU confidential. The European Parliament's involvement in EU security and defence policy, "Journal of Common Market Studies” 2015, Vol. 53, nr 2, [online] https://doi. org/10.1111/jcms.12154. 
Data

Tytul debaty

(w j. angielskim)
Liczba

wypowiedzi

18

17

10

12 VI 2013 Partnership and cooperation agreement with Afghanistan

Źródło: opracowanie własne.

Po roku 2013 kwestia Afganistanu nie była już w ogóle dyskutowana na plenarnych posiedzeniach Parlamentu Europejskiego. Wyraźnie widać też, że PE częściej interesował się tematem Afganistanu w momencie, gdy sytuacja bezpieczeństwa w tym kraju pogarszała się, a siły międzynarodowe przestawały sobie radzić z jego stabilizacją - w 2008 r. odbyły się dwie debaty, a w 2009 aż trzy dyskusje plenarne poświęcono tej tematyce. Wydaje się, że może to być związane z uruchomieniem w 2007 r. misji policyjnej EUPOL Afghanistan, aczkolwiek w analizowanych debatach deputowani stosunkowo rzadko odnoszą się do tej konkretnej operacji.

Wyznacznikiem zainteresowania europejskich deputowanych tematem bezpieczeństwa i stabilizacji w Afganistanie może być też liczba wypowiedzi podczas debat. Pomimo że polityka zagraniczna Unii Europejskiej nie stanowi głównego obszaru zainteresowań Parlamentu Europejskiego, a jego kompetencje w tym zakresie są niewielkie, to w niektórych kwestiach deputowani wypowiadają się bardzo obszernie - niejednokrotnie podczas debat dotyczących takich aspektów polityki zagranicznej, jak Europejska Polityka Sąsiedztwa, a zwłaszcza polityka rozszerzenia UE, średnia liczba wypowiedzi parlamentarzystów znacznie przekracza $40^{13}$, podczas gdy w analizowanym przypadku ledwo osiąga 18.

\section{PARLAMENT EUROPEJSKI - KONTESTATORZY}

W Parlamencie Europejskim deputowani zasiadają ze względu na swoją przynależność frakcyjną, a nie narodową. Niemniej tożsamość narodowa europarlamentarzystów nie pozostaje bez wpływu na ich wypowiedzi, wobec czego obie zostały wzięte pod uwagę w tej analizie jako zmienne. Ilościowa analiza wypowiedzi wskazuje, że w latach 2005-2013 najbardziej aktywnymi kontestatorami i komentatorami efektywności interwencji międzynarodowej i polityki UE oraz jej państw członkowskich w Afganistanie byli konserwatywni europarlamentarzyści z Polski. Polacy najczęściej udzielali się w debatach, co mogło być spowodowane znaczną liczebnością personelu wojskowego z Polski w Afganistanie. Interesujące jest natomiast, że eurodeputowani z Wielkiej Brytanii, których zaangażowanie w działania militarne w Afganistanie było dużo większe niż w przypadku Polski, byli mniej aktywni niż ich koledzy znad Wisły. Wydaje się, że jest

13 Badania własne w ramach projektu: Kontrola demokratyczna i legitymizacja Europejskiej Polityki zagranicznej... 
to pochodną dwóch faktów: po pierwsze w brytyjskiej Izbie Gmin kwestia interwencji w Afganistanie jest dyskutowana bardzo często i bardzo obszernie (ok. 70 debat w podobnym okresie, podczas gdy w Sejmie RP tylko 16). Po drugie interwencje wspierające pokój są domeną państw narodowych, więc logiczne jest, że dyskusja nad ich przebiegiem toczy się bardziej intensywnie właśnie w parlamentach narodowych. Dodatkowo parlament brytyjski jest organem, w którym debaty są bardzo rozbudowane i pełnią istotną funkcję kontrolną, stanowiąc podstawowe forum wymiany $i$ konfrontacji poglądów, kontestacji wszelakich polityk ${ }^{14}$, w tym również polityki bezpieczeństwa.

Poza Polską i Wielką Brytanią głos zabierali często eurodeputowani z Rumunii (również posiadającej swój znaczny kontyngent w ramach ISAF - misji NATO w Afganistanie) oraz Francji i Niemiec. Jeśli chodzi o przynależność frakcyjną, to reprezentacja w Parlamencie bezpośrednio przekładała się na częstość zabierania głosu - czyli najwięksi mówili najczęściej, co nie jest w żadnej mierze zaskakującym wynikiem. Tabela poniżej przedstawia całościowe zestawienie liczby wypowiedzi deputowanych ze względu na przynależność frakcyjną i narodowościową zabierającego głos.

Tabela 3. Liczba wypowiedzi europarlamentarzystów na temat zaangażowania w Afganistanie. Podział ze względu na przynależność frakcyjną i narodowość

\begin{tabular}{|c|c|c|c|c|c|c|c|c|c|c|c|c|c|}
\hline 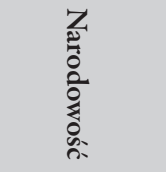 & 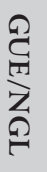 & 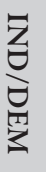 & Z & $\underset{t}{2}$ & $\stackrel{1}{0}$ & 界 & $\mathscr{\approx}$ & 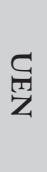 & 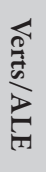 & $\sqrt[7]{7}$ & 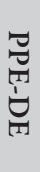 & $\overrightarrow{\mathscr{n}}$ & $\mathfrak{\Xi}^{\mathscr{E}}$ \\
\hline $\begin{array}{l}\text { Luksemburg } \\
\text { (LUX) }\end{array}$ & & & & 1 & & & & & & & & & 1 \\
\hline $\begin{array}{l}\text { Łotwa } \\
\text { (LV) }\end{array}$ & & & & & & & & & & & 1 & & 1 \\
\hline $\begin{array}{l}\text { Holandia } \\
\text { (NL) }\end{array}$ & & 3 & & 1 & & 1 & 2 & & & & & 1 & 8 \\
\hline $\begin{array}{l}\text { Irlandia } \\
\text { (IRL) }\end{array}$ & 1 & & & & & & & 1 & & & & 1 & 3 \\
\hline $\begin{array}{l}\text { Włochy } \\
\text { (IT) }\end{array}$ & 3 & & 2 & 3 & & & 2 & 2 & & 4 & 3 & & 19 \\
\hline $\begin{array}{l}\text { Litwa } \\
\text { (LT) }\end{array}$ & & & & & & & & & & & 2 & & 2 \\
\hline $\begin{array}{c}\text { Polska } \\
(\mathrm{PL})\end{array}$ & & 2 & 1 & 1 & 3 & 1 & 4 & 11 & & 5 & 3 & 8 & 39 \\
\hline $\begin{array}{l}\text { Stowenia } \\
\quad(\mathrm{SL})\end{array}$ & & & & 2 & & & 1 & & & & 1 & & 4 \\
\hline
\end{tabular}

14 Zob. I. Inigo-Mora, Rhetorical strategies in the British and Spanish parliaments, [w:] European Parliaments under Scrutiny, red. C. Ilie, Amsterdam 2010, s. 335, Discourse Approaches to Politics, Society, and Culture, 38. 


\begin{tabular}{|c|c|c|c|c|c|c|c|c|c|c|c|c|c|}
\hline $\begin{array}{l}Z \\
Z \\
0 \\
0 \\
0 \\
0 \\
0 \\
0 \\
\vdots \\
\vdots\end{array}$ & 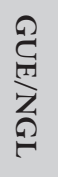 & 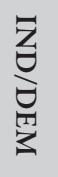 & Z & 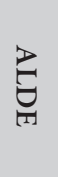 & $\stackrel{7}{7}$ & 罚 & $\mathscr{\gtrless}$ & $\begin{array}{l}\text { 秀 } \\
\text { Z }\end{array}$ & 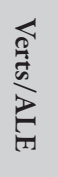 & $\sqrt[7]{7}$ & 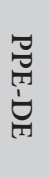 & 氙 & $\Xi_{\varpi}^{\infty}$ \\
\hline $\begin{array}{c}\text { Szwecja } \\
(\mathrm{SV})\end{array}$ & & 1 & & 1 & & & & & & & 1 & 1 & 4 \\
\hline $\begin{array}{c}\text { Wielka } \\
\text { Brytania } \\
\text { (UK) }\end{array}$ & & 3 & 5 & 4 & 4 & 1 & 1 & & 2 & & 6 & 7 & 33 \\
\hline $\begin{array}{l}\text { Portugalia } \\
\text { (PT) }\end{array}$ & 1 & & & & & & 3 & & 1 & & & 4 & 9 \\
\hline $\begin{array}{l}\text { Rumunia } \\
\text { (RO) }\end{array}$ & & & & 3 & & & 5 & & & 6 & 8 & 3 & 25 \\
\hline $\begin{array}{c}\text { Słowacja } \\
(\mathrm{SK})\end{array}$ & & & & & & 2 & 1 & & & 1 & 3 & & 7 \\
\hline $\begin{array}{c}\text { Czechy } \\
\text { (CS) }\end{array}$ & 3 & & & & & & 1 & & & & 1 & 4 & 9 \\
\hline $\begin{array}{l}\text { Cypr } \\
(\mathrm{CY})\end{array}$ & 1 & & & 2 & & & & & & 3 & & & 6 \\
\hline $\begin{array}{l}\text { Dania } \\
\text { (DK) }\end{array}$ & & & & 1 & & & & & & & & & 1 \\
\hline $\begin{array}{l}\text { Austria } \\
\text { (AT) }\end{array}$ & & & 2 & & & & & & & & 3 & 2 & 7 \\
\hline $\begin{array}{c}\text { Belgia } \\
(\mathrm{BE})\end{array}$ & & & 2 & 2 & & & & & & & & & 4 \\
\hline $\begin{array}{c}\text { Bułgaria } \\
(B G)\end{array}$ & & & 1 & & & & 1 & & & & 2 & & 4 \\
\hline $\begin{array}{c}\text { Niemcy } \\
\text { (DE) }\end{array}$ & 4 & & & 1 & & & 1 & & 5 & 3 & 9 & 4 & 27 \\
\hline $\begin{array}{l}\text { Finlandia } \\
(\mathrm{FI})\end{array}$ & 1 & & & 3 & & & 1 & & 1 & 3 & 2 & & 11 \\
\hline $\begin{array}{c}\text { Francja } \\
(\text { FR) }\end{array}$ & 2 & & 2 & 4 & & & 1 & & 6 & 7 & & & 22 \\
\hline $\begin{array}{l}\text { Węgry } \\
\text { (HU) }\end{array}$ & & & 1 & & & & & & & & & 2 & 3 \\
\hline $\begin{array}{c}\text { Estonia } \\
\text { (EE) }\end{array}$ & & & & 1 & & & & & & & 2 & 1 & 4 \\
\hline $\begin{array}{c}\text { Grecja } \\
(\mathrm{EL})\end{array}$ & 3 & 2 & & & & & & & & 1 & 2 & 1 & 9 \\
\hline $\begin{array}{l}\text { Hiszpania } \\
\quad(\mathrm{ES})\end{array}$ & 2 & & & & & & 1 & & 3 & 2 & 3 & 4 & 15 \\
\hline Razem & 21 & 11 & 16 & 30 & 7 & 5 & 25 & 14 & 18 & 35 & 52 & 43 & 277 \\
\hline
\end{tabular}

Źródło: opracowanie własne. 


\section{PARLAMENT EUROPEJSKI - ŻĄDANIA, ARGUMENTY, UZASADNIENIA}

Systematyczna analiza debat na temat Afganistanu w Parlamencie Europejskim ujawniła kilka kategorii, koncepcji czy zagadnień, do których najczęściej odwoływali się deputowani, gdy wyrażali swoje sądy i żądania polityczne odnoszące się do efektywności podejmowanych przez społeczność międzynarodową działań. Już wstępne wyniki tej analizy są interesujące, biorąc pod uwagę fakt, że najbardziej istotnym terminem (wedle wskazań współczynnika TFIDF) we wszystkich analizowanych debatach w PE jest słowo women. Sugeruje to, że eurodeputowani rozpatrują efektywność działań społeczności międzynarodowej w Afganistanie pod kątem praw człowieka, a zwłaszcza sytuacji kobiet.

Dalsza analiza wypowiedzi w debatach dotyczących Afganistanu przeprowadzona została w oparciu o koncepcję cyklu prowadzenia polityki, składającego się po pierwsze z ustalania agendy (ale w związku z faktem, że analizowanej polityce nadano już bieg dużo wcześniej, ten etap został pominięty w analizie), następnie formułowania polityki (tj. jej strategicznego kierunku czy np. obszaru geograficznego) oraz jej implementacji, instrumentów, za pomocą których jest realizowana ${ }^{15}$. Widoczne efekty danej polityki i ich ocena również zostały wzięte pod uwagę. Oprócz tego podjęto próbę identyfikacji adresatów żądań politycznych wysuwanych przez eurodeputowanych.

\section{FORMULOWANIE POLITYKI}

Jeśli chodzi o formułowanie polityki UE oraz innych członków społeczności międzynarodowej względem Afganistanu, najczęściej pojawiały się oceniające wypowiedzi polityków, które bądź krytykowały jej kierunek strategiczny, bądź - dużo rzadziej stwierdzały poprawną strategię. Często również w tym kontekście pojawiały się żądania polityczne o większym zaangażowaniu UE w czynności planistyczne na poziomie strategicznym. Krytyka podejścia strategicznego UE do konfliktu w Afganistanie opiera się wedle słów eurodeputowanych na kilku kluczowych kwestiach:

a) braku regionalnego podejścia do rozwiązywania konfliktu,

b) nieuwzględnieniu pewnych norm polityczno-kulturowych istniejących w Afganistanie,

c) swego rodzaju powierzchowności i krótkotrwałości działań podejmowanych przez UE,

d) zbyt militarystycznego podejścia do rozwiązywania konfliktu.

Brak regionalnego podejścia w polityce UE skierowanej do Afganistanu krytykowany jest przede wszystkim ze względu na lekceważenie państw sąsiednich, w tym głównie

15 Zob. szerzej: V.A. Schmidt, Democracy and legitimacy in the European Union revisited output, input and throughput, „Political Studies” 2013, Vol. 61, nr 1, [online] https://doi.org/10.1111/j.1467$-9248.2012 .00962 . x$. 
Pakistanu i jego polityki. Jak zauważa jeden z belgijskich europosłów: To, czego brakuje mi w zaproponowanym raporcie, to stwierdzenie, że zwyciestwo nad Talibami wymaga strategii względem Pakistanu, którego terytorium ciagle funkcjonuje jako schronienie dla terrorystów. Polityka względem Afganistanu musi być zatem zintegrowana z polityka względem catego regionu; w innym wypadku skazana będzie na porażkę ${ }^{16}$. W połączeniu z podobnymi argumentami pojawiają się też pretensje do władz Pakistanu o to, że jest pasywny w sprawie bojowników z Afganistanu, a pakistańskie siły zbrojne zawierają z nimi nieoficjalny pokój.

Co do realiów polityczno-kulturowych w Afganistanie, to w kontekście strategicznego planowania działań w tym rejonie kontestowano pewną naiwność, jeśli chodzi o możliwość wprowadzenia w tym kraju rządów demokratycznych na wzór Zachodu, oraz pewnego rodzaju idealizm co do możliwości wprowadzenia europejskich wartości w miejscu, gdzie nie są zaspokajane podstawowe potrzeby populacji. Przy okazji tego typu krytyki niejednokrotnie pojawiały się odniesienia do historycznych interwencji w innych zakątkach globu. Jak zauważa jeden z lewicowych deputowanych w PE: $W y$ darzenia $w$ Afganistanie przypominaja poniekad te $z$ Czeczenii ${ }^{17}$. W podobnym tonie i z przekąsem wypowiedział się w tej kwestii jeden z niezrzeszonych parlamentarzystów z Wielkiej Brytanii, który „przypomniał” autorowi raportu dla PE, włoskiemu deputowanemu Pino Arlacchiemu, że choć raport jest dobrze udokumentowany, to jego autor zdaje się obwiniać wtadze Afganistanu o to, że kraj ten nie jest nowoczesna demokracja rządzona przez koalicje Zielonych i Liberalnej Demokracji18.

Pojawiają się także argumenty kontestujące całokształt strategii UE względem Afganistanu czy nawet mówiące o jej braku. Padają one z ust deputowanych po każdej stronie sceny politycznej, a wagę nadaje im choćby fakt, że wypowiadane są przez deputowanego, którego można uznać za głównego specjalistę, jeśli chodzi o problem Afganistanu w Parlamencie Europejskim, wspomnianego już wcześniej Pino Arlacchiego. Arlacchi jest autorem dwóch raportów na temat polityki UE w Afganistanie ${ }^{19}$, a tematyka ta jest mu bliska zapewne w związku z piastowaniem przez niego funkcji dyrektora United Nations International Drug Control Program pod koniec lat 90., gdzie zajmował się głównie staraniami o globalne zmniejszenie upraw opium. W debatach PE odgrywa on rolę jednego z głównych kontestatorów polityki UE, dzięki chociażby takim stwierdzeniom:

Potrzebujemy nowej strategii - a może po prostu w ogóle potrzebujemy strategii zwtaszcza w aspekcie cywilnym, ponieważ do tej pory interwencji UE $w$ tym kraju brakowato spójności i wydaje się, że przetożyto się to na ograniczony wptyw na sytuację. Obawiam sie, pani Ashton, że nie moge zgodzić się z Pani wprowadzajacym wystapieniem na

\footnotetext{
Koenraad Dillen, NI, BE, 2008.

17 Erik Meijer, GUE/NGL, NL, 2009.
}

18 Andrew Henry William Brons, NI, UK, 2010.

19 European Parliament, Report on a new strategy for Afghanistan, 2009/2217(INI), [online] http:// www.europarl.europa.eu/sides/getDoc.do?pubRef=-//EP//NONSGML+REPORT+A7-2010$-0333+0+\mathrm{DOC}+\mathrm{PDF}+\mathrm{V0} / / \mathrm{EN} \&$ language $=\mathrm{EN}, 3$ III 2016. 
temat Afganistanu, gdyż jest ono zbyt ogólne, zbyt biurokratyczne, zbyt rozmyte - tak jak obecny plan dziatań [Komisji]. Uważam, że Parlament musi przyczynić się do wzmocnienia i skonkretyzowania naszej strategii ${ }^{20}$.

Wypowiedź ta dotyka nie tylko kwestii strategii, lecz także związanej z nią implementacji działań UE oraz, co interesujące, kontestuje działania konkretnych instytucji UE i kieruje w jej stronę jasno sprecyzowane żądanie polityczne. W tym przypadku chodzi o Komisję Europejską (tu uosobioną przez wysoką przedstawiciel Catherine Ashton) oraz sam Parlament Europejski - czyli instytucje UE, co w przypadku debat w PE jest oczywiste. W dalszej części tego artykułu zostanie ukazane szersze grono adresatów żądań, należy jednak nadmienić, że w przeważającej części wypowiedzi parlamentarzystów tacy adresaci nie istnieją albo są formułowani w sposób bardzo ogólny (np. żądania kierowane są do Unii Europejskiej jako całości).

Wśród eurodeputowanych jednymi z najczęściej wymienianych niedostatków, jeśli chodzi o formułowanie polityki względem Afganistanu, są także kwestie dotyczące strategii wejścia do Afganistanu i wyjścia z niego. Częstokroć pojawiają się głosy, że interwencja była zbyt zmilitaryzowana od początku, co w efekcie nie przyniosło poprawy sytuacji, ponieważ żadna strategia, a zwtaszcza środki militarne, nie ma szans na sukces w Afganistanie. Liczba żotnierzy wzrosta z 20 tysięcy w 2001 r. do ponad 150 tys. dziś, a sytuacja braku bezpieczeństwa tylko się pogtębita ${ }^{21}$. Brak jakiegokolwiek pomysłu na strategię wyjścia z Afganistanu również zdaje się budzić frustrację u europosłów. Frustracja ta połączona jest nie tylko z krytyką braku pomysłu na to, jak się wycofać, lecz także, co bezpośrednio z tym związane, $\mathrm{z}$ wyrażaniem niezadowolenia z powodu faktu, iż cele strategiczne zaangażowania od początku nie były klarowne ${ }^{22}$. Jak już wspomniano, bardzo często tego typu apele, pytania czy żądania pozostają bez adresata, i tak też jest w powyższym przypadku.

W odróżnieniu od tych pesymistycznych stanowisk można doszukać się też głosów, wedle których Unia Europejska oraz społeczność międzynarodowa mogłyby odgrywać większą rolę w Afganistanie. W wypowiedziach niektórych deputowanych można zauważyć konstruktywne podejście do tematu, a nawet propozycje konkretnych zagadnień strategicznych, na podstawie których powinna być formułowana polityka względem Afganistanu. Dobrym przykładem jest wystąpienie polskiego europosła, który proponuje zbudowanie zaangażowania $\mathrm{w}$ tym kraju na trzech filarach: dwuletnim intensywnym zaangażowaniu militarnym, dzięki któremu uda się pozbyć Al-Kaidy, a nastawionych pojednawczo Talibów wcielić do rządu afgańskiego; ustabilizowaniu sytuacji w regionie z uwzględnieniem Pakistanu i Indii; zbudowaniu społeczeństwa obywatelskiego $^{23}$. Niestety deputowany nie precyzuje, czy działania te miałyby się toczyć równolegle, i tradycyjnie już swoją propozycję kieruje w próżnię, nie uściślając, kto miałby taki zamysł w ramach UE (lub poza nią) realizować.

\footnotetext{
Pino Arlacchi, ALDE, IT, 2009.

Thijs Berman, S\&D, NL, 2010.

22 Elmar Brok, PPE, DE, 2009.

23 Piotr Borys, PPE, PL, 2009.
} 
W relatywnie wielu wypowiedziach można zauważyć żądania polityczne wskazujące na możliwy większy udział UE w Afganistanie czy też, zgodnie ze słowami jednego z deputowanych, domaganie się europejskiego podejścia do Afganistan $u^{24}$. Podstawowym uzasadnieniem tego żądania jest przekonanie niektórych parlamentarzystów o specjalnych instrumentach, wiedzy i zdolnościach Unii Europejskiej, których brak u innych aktorów, a które są kluczowe z punktu widzenia budowania pokoju - niemożność opanowania sytuacji środkami militarnymi predestynuje Unię Europejska, która posiada bogata gamę narzędzi, do odgrywania wyjątkowej roli [w Afganistanie $]^{25}$ - a dzięki którym UE będzie mogła wraz z NATO odgrywać wiodąca role $w$ międzynarodowych wysitkach na rzecz suwerennego Afganistanu ${ }^{26}$. Przytoczone powyżej wypowiedzi prezentują raczej skrajnie optymistyczną wizję rzeczywistości, natomiast w podobnym tonie, ale bardziej realistycznie twierdzi się, że samo cywilne nastawienie UE do rozwiązywania konfliktów nie wystarczy, jeśli nie będzie poparte odpowiednimi nakładami finansowymi i spójnością oraz konsekwencją w prowadzeniu polityki względem Afganistanu ${ }^{27}$.

Warto jeszcze wspomnieć o przypadkach, gdy eurodeputowani stwierdzali, że zaangażowanie UE w Afganistanie zostało poprawnie zaprojektowane. Udało mi się odnaleźć jedynie dwa fragmenty wypowiedzi, które argumentują, że sposób zaangażowania w Afganistanie nie był opatrzony błędem. Pierwszy mówi o założeniu, że interwencja w Afganistanie ma uniemożliwić Al-Kaidzie koordynowanie ataków terrorystycznych z tamtego terytorium, co zresztą udało się osiągnąc ${ }^{28}$. Drugi fragment przejawia bezkrytyczność wobec wypracowanej przez UE i jej sojuszników podczas szczytu NATO w Bukareszcie strategii ${ }^{29}$.

\section{IMPLEMENTACJA POLITYKI - ZAANGAŻOWANIE MILITARNE}

Kolejnym stadium cyklu prowadzenia polityki jest jej implementacja, czyli użycie odpowiednich instrumentów służących do osiągnięcia wyznaczonych w fazie formułowania polityki celów ${ }^{30}$. Jeśli chodzi o implementację działań UE w Afganistanie oraz ocenę efektywności i zasadności użytych narzędzi, a także o żądania polityczne posłów co do ich stosowania, najpierw zajmę się ogólną analizą, a później kilkoma specyficznymi problemami, które eurodeputowani uznali za istotne. W przypadku interwencji w konflikcie asymetrycznym toczy się debata na temat tego, na ile kampania COIN (ang. Counterinsurgency) powinna być skoncentrowana na populacji, a na ile

24 Ivo Vajgl, ALDE, SL, 2009.

25 Charles Goerens, ALDE, LUX, 2009.

26 Elena Băsescu, PPE, RO, 2010.

27 Roberto Gualtieri, S\&D, IT, 2009.

28 Erik Meijer, GUE/NGL, NL, 2009.

29 Cristian Dan Preda, PPE, RO, 2010.

30 Zob. Handbook of Public Policy Analysis. Theory, Politics, and Methods, red. F. Fischer, G.J. Miller, M.S. Sidney, London 2006, s. 51. 
na rzeczywistej walce z nieprzyjacielem. Innymi słowy, czy potrzebne jest większe zaangażowanie kinetyczne, czy raczej należy skupić się na "operacjach innych niż wojna” (operations other than war-OOTW). Debaty parlamentarne w Parlamencie Europejskim również rozważają te dwie alternatywy. Biorąc pod uwagę fakt, że słowo women jest najbardziej istotne w wypowiedziach europarlamentarzystów, można domyślać się, którą strategię COIN będą oni uważać za bardziej efektywną.

Błędem byłoby jednak stwierdzenie, że wszyscy deputowani uznają środki militarne czy kinetyczne za mało efektywne. Nie brakuje wypowiedzi, które pochwalają zwiększanie militarnego zaangażowania w Afganistanie, choć należy przyznać, że spośród 17 zidentyfikowanych głosów w debatach popierających siłę militarną jako możliwy klucz do zakończenia konfliktu, w aż 14 przypadkach pojawiała się wzmianka, że zaangażowanie cywilne jest równie istotne. Pozostałe trzy głosy również trudno zakwalifikować jako skrajnie militarystyczne, ale jednak wprost mówiące o potrzebie zwiększenia personelu wojskowego: Myślę, że niektórzy europejscy sojusznicy tylko mówią, że popieraja dziatania w Afganistanie, ale nic nie robią. Potrzebujemy więcej oddziatów bojowych, więcej elastyczności, większego poparcia dla misji ISAF ${ }^{31}$. Najostrzej w tej kwestii wypowiedział się francuski deputowany, twierdząc, że sprzeciwianie się zwiększaniu obecności wojskowej w Afganistanie jest przejawem antyamerykanizmu i samobiczowania się państw Zachodu oraz przyczyną całego zła w Afganistanie ${ }^{32}$. W kwestii dyskusji na temat zaangażowania militarnego pewne kontrowersje wywołała również sprawa legalności i zasadności użycia bezzałogowych pojazdów latających (unmanned aerial vehicles - UAV), zwanych potocznie dronami. Co interesujące, w Parlamencie Europejskim podczas debat na temat Afganistanu europarlamentarzyści nie wyrażali większego sprzeciwu wobec wykorzystywania tej technologii czy to do działań kinetycznych, np. w północno-wschodniej części kraju ${ }^{33}$, czy w celu ochrony własnego personelu ${ }^{34}$.

Po przeciwnej stronie stoją eurodeputowani, którzy uważają, że za nieefektywność społeczności międzynarodowej w radzeniu sobie z sytuacją w Afganistanie należy winić właśnie zbyt duże zaangażowanie militarne, w związku z czym powinno ono zostać zredukowane. Do tej grupy kwalifikuje się również 17 wypowiedzi, w których można doszukać się kilku uzasadnień takiej postawy. Po pierwsze niektóre wypowiedzi świadczą o tym, że deputowani traktują UE jako twór w pewien sposób wyjątkowy, jeśli chodzi o używanie siły, twór, który, w odróżnieniu od Stanów Zjednoczonych, posiada kulturę strategiczną bazującą na nieużywaniu siły ${ }^{35}$. W związku z tym pojawia się żądanie polityczne jasnego i zdecydowanego zdystansowania wobec działań USA w ramach operacji Enduring Freedom, a skupienie swojej energii na rekonstrukcji w ramach

31 Geoffrey Van Orden, PPE-DE, UK, 2008.

32 Philippe Juvin, PPE, FR, 2010.

33 Carlo Fidanza, PPE, IT, 2010.

34 Krzysztof Lisek, PPE, PL, 2010.

35 C.O. Meyer, Convergence towards a European strategic culture? A constructivist framework for explaining changing norms, „European Journal of International Relations” 2005, Vol. 11, nr 4, s. 523-549, [online] https://doi.org/10.1177/1354066105057899. 
ISAF $^{36}$. Wypowiedzi sprzeciwiające się zwiększaniu zaangażowania militarnego stają się bardziej widoczne w 2009 r., kiedy dochodzi do Afghan Surge - prezydent Obama decyduje o wysłaniu dodatkowych kilkudziesięciu tysięcy żołnierzy do Afganistanu. Pojawiają się głosy o tym, że Afganistan będzie Wietnamem XXI $w .^{37}$, przytaczane są też historyczne porażki Brytyjczyków i Sowietów w kampaniach afgańskich w XIX i XX w. jako lekcja, z której powinno się wyciągnąć wniosek, że kampania militarna będzie nieskuteczna. Należy zaznaczyć, że powyższe wypowiedzi nie negują całkowicie zaangażowania militarnego, ale uznają jego zastosowanie za nieefektywne, jeśli jest ono dominujące i nie idzie w parze z działania cywilnymi. Argument mówiący o tym, że Europa jest potegga cywilna $a^{38}$, ma w pamięci okropieństwa II wojny światowej i w związku $\mathrm{z}$ tym nie powinna mieszać się $\mathrm{w}$ działania wojenne, ostatecznie wzmocniony zostaje powołaniem się na głos obywateli UE:

Wspótczesna UE jest zbudowana na awersji do wojny [...]. W kwestii Afganistanu obywatele UE mocno popieraja podejście cywilne jako alternatywę do użycia sity. Nasze podejście nie jest naiwne, to nie delikatna Wenus przeciwko silnemu Marsowi. Zamiast tego to sita rozumu i ludzkiej solidarności powinna być używana przy rozwiązywaniu afgańskiego kryzysu, a nie uproszczona mentalność i wynikajace z niej rozwiazania ${ }^{39}$.

Jest to jedna z niewielu wypowiedzi, w których kwestia demokratycznej kontroli obywateli została poruszona przez parlamentarzystów. Europejczycy z Wenus ukazani są tu jako obdarzeni pewną mądrością, kierują się wartościami i wyrafinowaniem, w porównaniu do Amerykanów z Marsa, którzy do skomplikowanych problemów podchodzą bez przemyślenia i z rozwiązaniami siłowymi.

Ostatnią grupą, jeśli chodzi o kontestację zaangażowania Unii Europejskiej w Afganistanie, są ci deputowani, którzy sprzeciwiają się jakiemukolwiek udziałowi UE, a także społeczności międzynarodowej w rozwiązywaniu konfliktu w Afganistanie. Grono to nie jest liczne, skupia bowiem mniej niż 10 eurodeputowanych reprezentujących Zjednoczoną Lewicę Europejską - Nordycką Zieloną Lewicę (GUE/NGL) - oraz kilku deputowanych niezrzeszonych. W przypadku ich wypowiedzi mamy do czynienia z kontestacją totalną i żądaniami politycznymi wzywającymi do całkowitego wycofania się z interwencji. Wspólnym mianownikiem tych wypowiedzi jest nazywanie UE i USA imperialistami, a operacje w Afganistanie są określane jako okupacja, skutkująca ofiarami w ludności cywilnej. Wypowiedzi te wpisują się w nurt całkowitej demilitaryzacji Unii Europejskiej, wedle której Wspólna Polityka Zagraniczna i Bezpieczeństwa jest niepotrzebna i zbyt kosztowna, a Unia Europejska powinna być wyłącznie potęgą cywilną, taką, która nawet ekonomicznie nie wykorzystuje mniej rozwiniętych państw. Zwolennicy całkowitego braku zaangażowania powołują się na trzy główne argumenty:

36 Marie Anne Isler Béguin, Verts/ALE, FR, 2005. W trakcie wypowiadania tych sądów nie istniała jeszcze misja EUPOL Afghanistan.

37 Willy Meier, GUE/NGL, ES, 2009.

38 Zob. F. Duchêne, Europe's role in world peace, [w:] Europe Tomorrow. Sixteen Europeans Look Ahead, red. R. Mayne, London 1972, Fontana, 2730.

39 Pino Arlacchi, ALDE, IT, 2010. 
niechęć obywateli do obecności UE w Afganistanie ${ }^{40}$, obciążenia finansowe dla podatników w państwach członkowskich, jakie się z tym wiążą ${ }^{41}$, oraz koszty związane ze stratami w ludziach ${ }^{42}$.

\section{IMPLEMENTACJA POLITYKI - ZAANGAŻOWANIE CYWILNE}

Zaangażowanie w działalność cywilną w Afganistanie nie budzi już tak wielkich emocji jak w przypadku działań militarnych. W ponad 35 wypowiedziach deputowani odnoszą się pozytywnie do tego, by UE i społeczność międzynarodowa aktywnie i na wielu płaszczyznach działały w tym aspekcie. Ta sfera działalności stanowi swego rodzaju niszę, domenę, w której UE mogłaby się realizować, gdyż posiada odpowiednie instrumenty i doświadczenie, którymi żaden inny podmiot należący do społeczności międzynarodowej działający w Afganistanie nie dysponuje. Pomimo faktu, że misji NATO w Afganistanie nie można określić jako tradycyjnej kampanii militarnej, to udział w niej w przeważającej liczbie biorą żołnierze. UE nie wysłała do Afganistanu kontyngentu wojskowego pod własnym szyldem - byłoby to zresztą nieuprawnione, gdyż zgodnie z porozumieniami „Berlin plus” z 2003 r. między NATO a UE, Unia będzie interweniować tylko w przypadku, gdy NATO nie będzie zainteresowane wysłaniem swoich sił (tzw. prawo pierwszej odmowy dla NATO), a gdyby do takiej interwencji doszło, NATO zobowiązuje się wspierać UE swoimi zasobami logistycznymi, planistycznymi i wywiadowczymi ${ }^{43}$. Kilka operacji w ramach Wspólnej Polityki Bezpieczeństwa i Obrony - CSDP (a wcześniej Europejskiej Polityki Bezpieczeństwa i Obrony - ESDP) zostało przeprowadzonych właśnie przy wykorzystaniu tego mechanizmu (m.in. operacja Althea w Bośni i Hercegowinie). Piszę o tym w tym miejscu, żeby zaznaczyć, iż w dyskusji nad rolą i możliwościami UE na arenie bezpieczeństwa międzynarodowego pojawiła się koncepcja, w której, podobnie jak niedostatki militarne UE kompensuje mechanizm „Berlin plus”, Unia Europejska mogłaby, dzięki swoim instrumentom cywilnym, kompensować niedostatki NATO w kwestiach niekinetycznych - tzw. Berlin plus in reverse ${ }^{44}$. Choć eurodeputowani nie odnoszą się wprost do tego pomysłu, to w ich wypowiedziach (niektóre z nich przytoczone były już wcześniej) znajduje ona odzwierciedlenie.

W przeciwieństwie do sytuacji przedstawionej uprzednio, wśród głosów o zmniejszeniu zaangażowania militarnego w przypadku aktywności w sferze cywilnej żaden europarlamentarzysta nie wypowiedział się negatywnie. Jak wspomniałem, nawet ci, którzy argumentowali, że dla zwiększenia efektywności operacji powinno się wzmocnić obecność wojskową, chwilę później dodawali, że działania niekinetyczne również

40 Nick Griffin, NI, UK, 2010.

41 Hélene Goudin, IND/DEM, SV, 2006.

42 Andrew Henry William Brons, NI, UK, 2009.

43 Zob. S. Keukeleire, T. Delreux, The Foreign Policy of the European Union, Basingstoke 2014, s. 176.

44 J. Howorth, Security and Defence Policy in the European Union, Basingstoke 2007, s. 176. 
powinny zostać zintensyfikowane. Stanowisko europosłów można zawrzeć w stwierdzeniu, że zaangażowanie w Afganistanie przyniesie odpowiednie efekty, jeżeli UE:

1. włączy się aktywnie we wsparcie władz afgańskich w budowaniu demokratycznych instytucji państwowych, zdolnych do zapewnienia integralności terytorialnej, oraz rozwoju społeczno-gospodarczego, ochrony praw człowieka i rządów prawa $^{45}$;

2. wesprze przywództwo Hamida Karzaia na stanowisku prezydenta Afganistanu ${ }^{46}$ oraz Habiby Sarabi jako gubernator prowincji Bamiyan ${ }^{47}$;

3. wzmocni proces rekoncyliacji wewnątrz państwa ${ }^{48}$;

4. wesprze geostrategiczne i dyplomatyczne wysiłki prowadzące do rozwiązania konfliktu, np. poprzez konsultacje z Pakistanem ${ }^{49}$;

5. pomoże finansowo i poprzez pomoc rozwojową ${ }^{50}$.

Katalog ten uzupełniają mniej liczne żądania polityczne z poprzedniej sekcji, o zwiększeniu zaangażowania militarnego celem zapewnienia odpowiedniego poziomu bezpieczeństwa. Uzasadnione jest też stwierdzenie, że to motyw większego bądź mniejszego zaangażowania militarnego jest najważniejszym elementem kontestacji ze strony europarlamentarzystów - w wypowiedziach na temat implementacji zaangażowania UE w Afganistanie to właśnie słowo military jest zarówno najbardziej istotne, jak i drugie (po słowie Afghanistan), jeśli chodzi o częstotliwość występowania.

Jak już wspomniałem, opinia, że zaangażowanie cywilne jest niezbędne do ustabilizowania Afganistanu, podzielana jest właściwie bez wyjątku przez członków Parlamentu Europejskiego. Przekonanie to jest na tyle silne, że nawet ci deputowani, którzy wyrażają żądanie wycofania się z Afganistanu albo przynajmniej jakiegoś planu opisującego, jak takie wycofanie ma wyglądać, sami przyznają, że dotyczy ono tylko wojska, a zaangażowanie cywilne potrzebne będzie także w okresie późniejszym ${ }^{51}$.

\section{IMPLEMENTACJA POLITYKI - OCENA EFEKTYWNOŚCI}

Poprzednie sekcje skupiły się na analizie żądań politycznych i argumentów wysuwanych przez europarlamentarzystów dotyczących tego, jak zaangażowanie UE w Afganistanie powinno być implementowane. Niżej przeanalizuję te wypowiedzi w debatach PE, w których eurodeputowani kontestują rzeczywiste działania UE, jej sojuszników czy władz Afganistanu. Zanim jednak skupię się na krytyce, przytoczę te głosy w debacie, które pozytywnie pod względem efektywności oceniły

\footnotetext{
45 Libor Rouček, PSE, CS, 2008.

46 Miroslav Mikolášik, PPE-DE, SK, 2008.

47 Nicole Kiil-Nielsen, Verts/ALE, FR, 2009.

48 Ioannis Kasoulides, PPE, CY, 2009; Roberto Gualtieri, S\&D, IT.

4 Willy Meyer, GUE/NGL, ES, 2009.

50 Ryszard Czarnecki, NI, PL, 2005; José Ignacio Salafranca Sánchez-Neyra, PPE, ES, 2009.

51 Ioannis Kassoulides, PPE, CY, 2012.
} 
implementację działań UE w Afganistanie. Jak nietrudno się domyślić, są one nieliczne, ale interesujący jest fakt, że pośród tych głosów najbardziej przychylne dotyczą właśnie zaangażowania militarnego, czyli działalności, która przez posłów jest najbardziej kontestowana. Należy tu jednak poczynić uwagę, że prawidłowo ocenia się implementację zaangażowania militarnego tylko w zakresie osiągania celów militarnych, a nie całości wysiłku na rzecz stabilizacji Afganistanu. Tak też kampania wojskowa oceniana jest jako sukces ${ }^{52}$, znaczacy militarny sukces ${ }^{53}$ czy sukces taktycz$n y^{54}$. Nie ma tu zatem mowy o sukcesie strategicznym, a raczej o powodzeniu tylko na pewnym wycinku (również geograficznym - często przywoływany w tym kontekście jest Kandahar) starań o stabilizację Afganistanu. Kilka pozytywnych wypowiedzi dotyczy również działalności cywilnej, zwłaszcza decyzji Komisji Europejskiej, by środki pomocowe dla Afganistanu były przekazywane bezpośrednio do struktur państwowych w Kabulu ${ }^{55}$, oraz działalności KE w sferze pomocy rozwojowej Specjalnemu Przedstawicielowi UE w Afganistanie ${ }^{56}$.

Dużo więcej uwagi parlamentarzyści poświęcają nieprawidłowościom w egzekwowaniu polityki względem Afganistanu. Jak łatwo się domyślić, i poniekąd paradoksalnie, również najwięcej krytyki dotyczy zbyt dużego zaangażowania militarnego, jednak oprócz tego przewijają się, a niekiedy nawet dominują pewne wątki dotyczące specyficznych aspektów zaangażowania w Afganistanie. Jak już wspomniałem, dobrym przykładem jest tu kwestia sytuacji kobiet. Jak pokazuje tabela 2, aż dwie debaty w całości poświęcone były temu problemowi, a w pozostałych dyskusjach kwestia ta jest również obecna. Jeden z deputowanych określił nawet całe zaangażowanie społeczności w Afganistanie mianem projektu feministycznego ${ }^{57}$. Nie dzieje się tak przypadkiem - po pierwsze, jako że Parlament Europejski jest tą unijną instytucją, która najchętniej reaguje na wszelkie naruszenia praw człowieka w państwach trzecich, jego reakcja na naruszenia praw kobiet w Afganistanie musi być widoczna. Po drugie istotny jest kontekst. Pierwsza debata o sytuacji kobiet w Afganistanie odbyła się w 2009 r. Wtedy też władze Afganistanu przyjęly legislację (shia family law), która w dość istotny sposób ograniczała prawa kobiet, m.in. zabraniała im opuszczania domu bez zezwolenia męża czy też legalizowała gwałt małżeński ${ }^{58}$.

Tego typu regulacje wywołały protesty wśród eurodeputowanych oraz żądania polityczne z nimi związane. W tym przypadku wiele postulatów dotyczących zniesienia wspomnianych regulacji było kierowanych na zewnątrz, do władz w Kabulu, ale również do Komisji Europejskiej, aby ta uczyniła ochronę praw kobiet jednym ze swoich

\footnotetext{
Konrad Szymański, UEN, PL, 2008.

Carlo Fidanza, PPE, IT, 2010.

Ioannis Kassoulides, PPE, CY, 2012.

Carl Haglund, ALDE, SV, 2010.

Nickolay Mladenov, PPE-DE, BG, 2008.

57 Erik Meijer, GUE/NGL, NL, 2009.

58 Zob. J. Starkey, Afghan leader accused of bid to „legalise rape”, [online] http://www.independent.co.uk/ news/world/asia/afghan-leader-accused-of-bid-to-legalise-rape-1658049.html, 10 VII 2017.
} 
strategicznych priorytetów w Afganistanie ${ }^{59}$. Problem dyskryminacji kobiet oraz związana z nim kwestia wolności słowa wyzwoliły w wypowiedziach deputowanych także elementy dyskursu bardzo normatywnego, postkolonialnego czy postimperialnego ${ }^{60}$, w którym Europa przedstawiona jest jako ta bardziej cywilizowana, od której wartości i sposób życia powinny przejmować ludy gorsze, pozostające cywilizacyjnie w tyle. Niektóre z wypowiedzi są bardzo dosadne i warte przytoczenia, jak ta wyrażona podczas debaty na temat skazania na śmierć afgańskiego dziennikarza:

Perwez Kambakhsh odważyt się rozpowszechnić artykut, który ściagnąt z Internetu, krytykujacy traktowanie kobiet przez islam. Ten odwazny czyn zostat zgodnie z prawem szariatu, które jest rodem z paleolitu, uznany za bluźnierstwo $i$ [dziennikarz] zostat skazany na śmierć przez pótmózgów, zaślepionych fanatyzmem tak zwanych sędziów, w tak zwanym sądzie regionalnym na pótnocy Afganistanu. Jak wiadomo, dla fanatycznych islamistów kobiety odgrywaja role niewiele ważniejszą niż meble w mieszkaniu [... ${ }^{61}$.

W przeważającej liczbie wypowiedzi na temat sytuacji kobiet w Afganistanie zawarte są sądy, że bez poszanowania ich praw o jakimkolwiek sukcesie w Afganistanie nie może być mowy.

Drugim po kobietach ważnym wątkiem w dyskusji nad implementacją działań w Afganistanie jest temat upraw opium. W tym elemencie deputowani już nie są aż tak emocjonalni, lecz nie szczędzą krytyki na temat tego, jak społeczność międzynarodowa radzi sobie z tym problemem. O ile w przypadku praw kobiet czy wolności słowa, pomimo krytyki, zauważane są także pozytywne przejawy działalności społeczności międzynarodowej, o tyle temat opium jest postrzegany jako porażka, a środki przeznaczone na program walki z narkotykami niektórzy uznają za skrajny przyktad marnotrawstwa $i$ nieefektywności ${ }^{62}$. Co interesujące, w przypadku upraw opium zwraca uwagę w wypowiedziach europosłów zauważenie szerszego kontekstu tego problemu - częściej niż w innych przypadkach twierdzą oni, że kluczem do efektywności w tej kwestii jest spójna polityka na poziomie regionu, a nawet globalne podejście do kwestii narkotyków, np. całkowita ich legalizacja ${ }^{63}$. Eurodeputowani widzą również właśnie w opium (a nie choćby w terroryzmie) jedno z największych zagrożeń, jakie niesie ze sobą brak stabilizacji w Afganistanie: Narkotyki wyprodukowane z tego opium sa tym, co niektórzy nazywaja rzeczywista bronia masowej zagtady, zwtaszcza w Europie ${ }^{64}$.

Oprócz kwestii poszanowania praw kobiet i problemu narkotykowego można doszukać się jeszcze kilku ważnych, konkretnych żądań politycznych dotyczących takich

59 Lissy Gröner, PSE, DE, 2009.

60 Szerzej na temat normatywnego dyskursu UE zob. J. Zielonka, Europe's new civilizing missions. The EU's normative power discourse, ,Journal of Political Ideologies” 2013, Vol. 18, nr 1, [online] https:// doi.org/10.1080/13569317.2013.750172.

61 Marios Matsakis, ALDE, CY, 2008. Perwez Kambakhsh został w końcu skazany na 20 lat więzienia, ale w 2009 r. ułaskawił go Hamid Karzai. Jeszcze przed ułaskawieniem został on w tajemnicy wywieziony z Afganistanu przez Szwedów.

62 Zoran Thaler, S\&D, SL, 2010.

63 Marios Matsakis, ALDE, CY, 2007.

64 Ana Maria Gomes, PSE, PT. 
niekinetycznych spraw, jak: reforma afgańskiego sektora bezpieczeństwa oraz procesu DDR (demobilisation, disarmament, reintegration), walka $\mathrm{z}$ korupcją i wprowadzanie dobrego rządzenia (good governance) czy zwiększenie i ulepszenie pomocy rozwojowej kierowanej do Afganistanu.

$\mathrm{Na}$ uwagę zasługuje fakt, że kontestując i wysuwając żądania polityczne wobec implementacji polityki UE czy nawet szerzej - państw europejskich, w Afganistanie, eurodeputowani stosunkowo rzadko odnoszą się do konkretnych przedsięwzięć, do specyficznych misji. W przeanalizowanym materiale posłowie wskazywali (choć sporadycznie) dwie misje: operację ISAF Sojuszu Północnoatlantyckiego oraz misję policyjną EUPOL-A. Jeśli chodzi o częstotliwość, to w kontekście kontestacji efektywności działań ISAF wspomniany został w 14, a misja unijna w 9 wypowiedziach. $Z$ jednej strony nie powinien zaskakiwać fakt, że zainteresowanie misją ISAF i EUPOL-A jest podobne. W końcu w ISAF uczestniczyło gros państw europejskich ${ }^{65}$, a zaangażowanie w tę operację pociągało za sobą istotne ryzyko ze względu na jej kinetyczny charakter. EUPOL-A jest z kolei operacją mniej ryzykowną i z założenia mniej kinetyczną, ale prowadzoną w ramach CSDP, toteż musi pojawiać się w dyskusjach. Z drugiej jednak strony dziwi tak rzadkie występowanie EUPOL-A w debatach. Dziwi dlatego, że operację tę można uznać za najtrudniejszą misję cywilną UE (realizowaną w dalece niestabilnym i niebezpiecznym środowisku, wystawioną na zagrożenia asymetryczne), więc można było się spodziewać większego zaangażowania europosłów w jej kontestację. Co więcej, to właśnie $\mathrm{w}$ analizowanym przedziale czasu misja ta została zaprojektowana i uruchomiona, a mimo to przez większość wypowiadających się deputowanych została ona pominięta. Należy w tym miejscu nadmienić, że sytuacja nieco inaczej wygląda w komisjach Parlamentu Europejskiego, a konkretnie w Podkomisji Bezpieczeństwa i Obrony (Security and Defence - SEDE). Tam kwestie związane z funkcjonowaniem EUPOL-A były dyskutowane, a nawet zdarzały się rozbudowane sesje tej podkomisji poświęcone w większości tej operacji (np. w 2010 r. ${ }^{66}$.

Pierwsze głosy w debatach na temat misji policyjnej UE pojawiły się dopiero w drugiej połowie 2008 r. i są pozytywne. Mówią one, że misja EUPOL jest nie do przecenienia i powinno się zastanowić nad rozszerzeniem jej mandatu ${ }^{67}$ oraz że wykonuje świetną robotę, choć i tak jest niczym w porównaniu do wysiłków Amerykanów ${ }^{68}$. W kolejnych latach podejście posłów uległo jednak zmianie i pojawiła się silna kontestacja i rozczarowanie tym, w jaki sposób EUPOL sprawuje swój mandat. Wydaje się, że podstawowym problemem implementacyjnym jest niedobór personelu policyjnego. Eurodeputowani

65 Państwa europejskie biorące udział w ISAF: Albania, Belgia, Bułgaria, Chorwacja, Czechy, Dania, Estonia, Francja, Niemcy, Grecja, Węgry, Islandia, Włochy, Łotwa, Litwa, Luksemburg, Holandia, Norwegia, Polska, Portugalia, Rumunia, Słowacja, Słowenia, Hiszpania, Turcja, Wielka Brytania, Armenia, Austria, Azerbejdżan, Bośnia i Hercegowina, Finlandia, Gruzja, Irlandia, Macedonia, Czarnogóra, Szwajcaria, Szwecja i Ukraina.

66 SEDE Draft agenda of the meeting on 25 January 2010, [online] http://www.europarl.europa.eu/ meetdocs/2009_2014/organes/sede/sede_20100125_1600.htm, 18 VII 2017.

67 Roberto Gualtieri, S\&D, IT, 2009.

68 Geoffrey Van Orden, PPE-DE, UK, 2008. 
ostro krytykują Cathrene Ashton nawet nie tylko za to, że misja nie jest w stanie osiągnąć wymaganego stanu osobowego, ale głównie dlatego, że wedle jej retoryki wszystko działa sprawnie: Twierdzi Pani, że państwa cztonkowskie poświęcaja dużo energii misji EUPOL. Czy aby na pewno? Jeśli tak, to jakim cudem wciąż nie jesteśmy w stanie umieścićtam 400 oficerów policji? To, co Pani mówi, to mieszanka nieszczerości i absurdu ${ }^{69}$. Innymi punktami krytycznymi wykorzystywanymi przez europosłów do kontestowania operacji są kwestie współpracy z NATO. Niektórzy uważają bowiem, że lepsza koordynacja działań między misją unijną a operacją Sojuszu i zwiększenia zaangażowania państw europejskich w misje NATO przyczyniłaby się do zwiększenia efektywności ${ }^{70}$. Ten sam deputowany w swojej wypowiedzi błędnie użył terminu „Europol”, wypowiadając się o misji policyjnej UE, co również może świadczyć o braku rozeznania i zainteresowania (przynajmniej niektórych) europosłów w dziedzinie CSDP. Z drugiej jednak strony może być świadectwem braku chęci informowania Parlamentu Europejskiego przez inne unijne instytucje. Jest to kolejny element kontestacji EUPOL, tym razem jednak dotyka on jej demokratycznej kontroli: Wiele dziśpowiedziano na temat Afganistanu, ale bardzo żatuje, że więcej nie mówiliśmy o misji EUPOL orazjej związku z dziataniami $N A T O^{71}$. Trudno się dziwić takim wypowiedziom parlamentarzystów, biorąc pod uwagę, ile czasu poświęcono na sesjach plenarnych tematyce polityki bezpieczeństwa UE w Afganistanie.

Jeżeli chodzi o misję ISAF, to nie była to operacja Unii Europejskiej, choć państwa europejskie brały w niej znaczący udział. Warto zaznaczyć, że wypowiedzi o ISAF stają się dla niektórych europosłów okazją do zaznaczenia swojej proatlantyckiej orientacji, jeśli chodzi o kwestie bezpieczeństwa i krytykę państw europejskich w związku z umiarkowanym zaangażowaniem w rozwiązywanie konfliktu (w przypadku posłów z Wielkiej Brytanii i Polski). Deputowani zauważają zgodnie, że to jednak misja NATO, a nie EUPOL, ma stanowić klucz do sukcesu w Afganistanie i pomimo faktu, iż niejednokrotnie pojawiały się przytaczane już argumenty, że to UE posiada odpowiednie zdolności i instrumenty cywilne do radzenia sobie z tego typu konfliktami, to jednak w PE nie pojawił się wprost głos sprzeciwu wobec wysłania przez prezydenta Obamę w 2009 r. dodatkowych sił do Afganistanu. Wręcz przeciwnie, decyzja była chwalona, choć wyrażano nadzieję, że żołnierze ci będą się przyczyniać do rekonstrukcji kraju, a nie do działań kinetycznych.

\section{ADRESACI ŻĄDAŃ}

Jak już kilkukrotnie wspomniano, europarlamentarzyści nie mają w zwyczaju kierować żądań politycznych do konkretnych adresatów, pomimo że niekiedy mają one bardzo konkretną formę. Wyjątkiem jest zatem sytuacja, kiedy posłowie kontestują działania, wyraźnie wskazując, do kogo się zwracają. Podczas systematycznej analizy debat udało

69 Reinhard Bütikofer, Verts/ALE, DE, 2009.

70 Zbigniew Ziobro, ECR, PL, 2010.

71 Arnaud Danjean, PPE, FR, 2009. 
się zidentyfikować kilka grup adresatów, a niekiedy konkretne instytucje, do których kierują swoje żądania polityczne deputowani. Nie dziwi fakt, że najwięcej żądań kierowanych jest do instytucji europejskich. Wśród pozostałych adresatów można wyróżnić także rządy państw, rząd Afganistanu, NATO, szeroko rozumianą społeczność międzynarodową czy sojuszników. Na poniższych diagramach widać również wyraźnie przepływ żądań pod kątem przynależności narodowej europosłów (rysunek 1). Przyjrzyjmy się zatem bliżej naturze stawianych przez deputowanych żądań kierowanych do konkretnych adresatów.

Rysunek 1. Adresaci żądań politycznych a narodowość eurodeputowanych

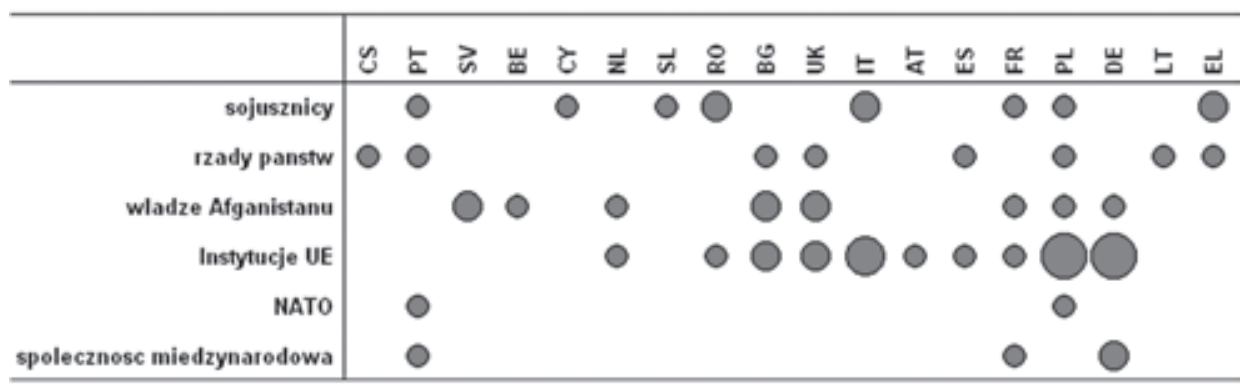

Źródło: opracowanie własne.

Jak widać na powyższym diagramie, zdecydowanie najwięcej żądań politycznych, a co za tym idzie kontestacji działań, kierowanych jest w stronę instytucji unijnych. Kategoria ta jest raczej różnorodna, dlatego należy sprecyzować, o jakie instytucje eurodeputowanym chodzi.

\section{Parlament Europejski}

Część żądań politycznych dotyczy instytucji, na forum której są one wypowiadane. Tak też jest w przypadku, gdy eurodeputowani kierują pewne wezwania do działania do Parlamentu Europejskiego. Naturę tych żądań można określić jako raczej jednolitą i realistyczną. Wypowiedzi europosłów skupiają się na dwóch zasadniczych kwestiach. Po pierwsze znakomita większość żądań adresowana do PE dotyczy spraw związanych z ochroną praw człowieka. Jak już wspomniano we wstępie do tego rozdziału, Parlament Europejski uważa się za tego, który stoi na straży podstawowych wartości UE (zarówno w wymiarze wewnętrznym, jak i zewnętrznym). Dlatego też najczęściej żądania wobec Parlamentu w przypadku analizowanych debat dotyczą zajęcia twardej postawy wobec łamania praw kobiet w Afganistanie ${ }^{72}$. Oprócz tego pojawiają się żądania nawiązania ściślejszej współpracy z parlamentarzystami afgańskimi, choć są one wysuwane jeszcze w 2005 r., przed pogorszeniem się sytuacji bezpieczeństwa w regionie. Na przykład jeden z posłów proponuje powołanie delegacji PE ds. kontaktów

72 Lidia Joanna Geringer de Oedenberg, PSE, PL, 2009; Lissy Gröner, PSE, DE, 2009. 
z Afganistanem ${ }^{73}$. Trzecim rodzajem żądań wysuwanych w stronę PE są te mówiące, że Parlament Europejski powinien zadbać o to, by jego głos był słyszalny w konstruowaniu polityki UE względem Afganistanu ${ }^{74}$. Wydaje się zatem, że żądania polityczne dotyczące Parlamentu Europejskiego, a wysuwane przez jego członków poniekąd potwierdzają tezę, że PE wciąż jest aktorem aspirującym do odgrywania większej roli w demokratycznej kontroli CSDP ${ }^{75}$. Parlamentarzyści z jednej strony skupiają się na wzywaniu Parlamentu do wykonywania tych zadań, w których ma już doświadczenie (ochrona praw człowieka), a z drugiej apelują o wzmocnienie jego roli. Interesująca jest jeszcze jedna kwestia - mianowicie podczas debat na temat Afganistanu praktycznie nie dochodzi do kontestacji wewnątrzparlamentarnej, nie kieruje się żądań i nie kontestuje wypowiedzi innych eurodeputowanych (brak tzw.partisan questions). Ostatecznie tego typu kontestacja odbywa się podczas głosowania, lecz w dyskursie parlamentarnym jest ona właściwe nieobecna. Posłowie nie korzystają w ogóle z procedur „niebieskiej karty” czy catch eye. Jednym z niewielu przejawów kontestacji poglądów opozycyjnych była wypowiedź polskiego MEP Konrada Szymańskiego, który, komentując poprawki do rezolucji proponowane przez lewicę, stwierdził, że są one przejawem egoizmu, hipokryzji i krótkowzroczności $i^{76}$.

\section{Komisja i Rada}

Te dwie instytucje UE są przeważnie traktowane przez eurodeputowanych łącznie. Przyglądając się dynamice debat, należy przypuszczać, że jest to po pierwsze spowodowane pewnym nawykiem - w PE stosowany jest właśnie tego rodzaju żargon. Po drugie większość analizowanych w tej pracy debat rozpoczyna się i kończy na wystąpieniach przedstawicieli Komisji Europejskiej i Rady Unii Europejskiej, więc nie dziwi fakt, że żądania częstokroć kierowane są do tych instytucji łącznie. Jeżeli natomiast deputowani kontestują działanie którejś z tych instytucji osobno, to prawie zawsze dotyczy to Komisji. Są to jednak nieliczne przypadki i dotyczą takich żądań, jak: zawarcie w przyszłości umowy stowarzyszeniowej z Afganistanem ${ }^{77}$, wejście w aktywne partnerstwo z organizacjami pozarządowymi przy rekonstrukcji Afganistanu ${ }^{78}$ czy, podobnie jak w przypadku Parlamentu Europejskiego, położenie większego nacisku na ochronę praw kobiet ${ }^{79}$.

W tym miejscu trzeba też nadmienić, że po wejściu w życie ustaleń Traktatu reformującego UE głównym reprezentantem zarówno Komisji, jak i Rady podczas plenarnych debat PE na temat Afganistanu stała się Wysoka Przedstawiciel Unii ds.

\footnotetext{
3 Jürgen Schröder, PPE-DE, DE, 2005.

74 Pino Arlacchi, ALDE, IT, 2009.

75 W. Wagner, The democratic control of military power Europe, "Journal of European Public Policy" 2006, Vol. 13, nr 2, s. 208-209.

76 Konrad Szymański, UEN, PL, 2008.

77 José Ignacio Salafranca Sánchez-Neyra, PPE-DE, ES, 2008.

78 Karin Scheele, PSE, AT, 2005.

79 Charles Tannock ECR, UK, 2011.
} 
Zagranicznych i Polityki Bezpieczeństwa. W związku z tym po 2009 r. to właśnie na niej skupiała się główna krytyka ze strony deputowanych. Dotyczyła ona żądania implementacji pewnych instrumentów politycznych, np. konsultacji i wspólpracy z Rosją i Tadżykistanem w kwestii Afganistanu ${ }^{80}$ czy cytowanej już w tej pracy wypowiedzi odnośnie do problemów z osiągnięciem przez EUPOL odpowiedniej liczby personelu. Oprócz tego kontestacja dotyczy także samej instytucji Wysokiej Przedstawiciel, a nawet konkretnej osoby, która tę funkcję sprawowała:

Chodzi mi przede wszystkim o brak doświadczenia wysokiej przedstawiciel do spraw zagranicznych, pani Cathy Ashton, która jest specjalistka od zrzucania problemów na cudze barki - a jest co zrzucać. Potrzebujemy kogoś bardziej doświadczonego. Nie dość, że pani Ashton nie pracowata $w$ Foreign Office, nie byta sekretarzem ds. zagranicznych, to jak sadze, nie pracowata nawet na pót etatu w biurze podróży. Jak mogto do tego dojść?! To stanowisko wymagajace delikatności, stanowisko, na którym trzeba zmieniać sprawy na lepsze, a na tym pani Ashton po prostu sięnie zna ${ }^{81}$.

\section{Rządy państw członkowskich UE}

Europarlamentarzyści nie kierują wielu żądań w stronę władzy wykonawczej (czy jakiejkolwiek innej) w krajach UE. Można przypuszczać, że uznają, iż to parlamenty narodowe powinny takie żądania wysuwać. Jeżeli już pojawia się w wypowiedziach deputowanych kontestacja skierowana do państw członkowskich, to dotyczy ona żądania zwiększania zaangażowania w Afganistanie przez niektóre kraje. Niekiedy mówi się ogólnie o państwach członkowskich, bez wymieniania konkretnych krajów, a niekiedy występują konkretne żądania kierowane do konkretnych rządów. W obu przypadkach są to jednak głosy marginalne, więc nie będą tu przytaczane. Wspomnę tylko, że w badanym studium przypadku nie występuje korelacja między narodowością eurodeputowanego a krajem, do którego kieruje swoje żądanie.

\section{Sojusznicy}

Eurodeputowani w kontestacji efektywności polityki względem Afganistanu oraz w wysuwaniu żądań politycznych odnośnie do jej przeprowadzania wychodzą także poza Europę. W tym przypadku, rzecz jasna, nie posiadają, oprócz możliwości wypowiedzenia się, choćby najmniejszej siły politycznej czy też wpływu na działania pozaeuropejskich aktorów. Dlatego możemy raczej mówić o apelowaniu, a nie żądaniu czegoś z możliwością wyegzekwowania. Jak nietrudno się domyślić, głównym adresatem tych apeli są sojusznicy. Analizując debaty PE na temat Afganistanu, w kategorii tej należy umieścić Stany Zjednoczone oraz NATO. Europosłowie właściwie nie wspominają o innych sojusznikach, jeśli chodzi o działalność w Afganistanie. Nie jest w tym przypadku zaskakujące, że deputowani milczą na temat zaangażowania ONZ w konflikt, ale

\footnotetext{
80 Janusz Władysław Zemke, S\&D, PL, 2009.

81 Nicole Sinclair, EFD, UK, 2009.
} 
zastanawiający może być np. brak Pakistanu. Co prawda państwo to występuje w wypowiedziach europosłów, ale traktowane jest w nich jako przedmiot, a nie podmiot tej polityki. Żądania polityczne wysuwane są nie do władz Pakistanu, lecz do np. instytucji UE, by te zajęły się sytuacją w Pakistanie lub też wzięły pod uwagę znaczenie tego kraju (oraz innych państw w regionie).

Wracając jednak do tych, których parlamentarzyści uważają za sojuszników: to zdecydowana większość żądań skierowana jest do USA i dotyczy albo zwiększenia zaangażowania, albo sposobu prowadzenia operacji: Jasne jest, że USA, panstwa sojusznicze i NATO nie moga się wycofać. Nasza nieustanna obecność i osiagnięcie sukcesu $w$ Afganistanie $w$ du$\dot{z}$ ej mierze zależa od politycznego i militarnego zaangażowania na poziomie międzynarodowym $[. . .]^{82}$. Jeżeli mowa o sposobie prowadzenia operacji, to dochodzi do kontestacji działań sojuszników. Głównymi jej elementami są głosy krytykujące tajne więzienia USA w Kabulu ${ }^{83}$ czy brak poszanowania dla kultury i tradycji mieszkańców Afganistanu ${ }^{84}$.

Występują również wypowiedzi wprost krytykujące sojuszników i ich zaangażowanie w konflikt, których efektem docelowym ma być wycofanie się z Afganistanu. Głosy te pochodzą ze strony europejskiej lewicy (zarówno mniej, jak i bardziej umiarkowanej), której przedstawiciele wręcz winią Amerykanów za dozbrajanie Talibów ${ }^{85}$ czy też żądają natychmiastowego wycofania się amerykańskich imperialistów ${ }^{86}$.

\section{Rząd Afganistanu}

Zauważalnym zjawiskiem jest stosunkowo niewielka liczba żądań, jeśli chodzi o władze Afganistanu. Kraj ten jest raczej przedmiotem polityki europejskiej, więc mówi się o nim, a nie do niego, niemniej jest także biorcą pomocy, wobec którego istnieją pewne oczekiwania. W tym duchu właśnie wypowiadają się europarlamentarzyści, to znaczy żądania wobec rządu afgańskiego są wyrażane w formie apeli, że władze będą robić więcej na rzecz..., pokaża, że zależy im na..., zademonstruja przywiazanie do... Dalej następuje zazwyczaj wzmianka o prawach człowieka czy odpowiedzialnym przywództwie (żądanie często kierowane osobiście do Hamida Karzaia).

\section{Społeczność międzynarodowa}

Kategoria ta obejmuje wszelkie inne instytucje, które nie zawierają się w kategoriach przeanalizowanych powyżej. W związku z tym, że Unia Europejska jest aktywnym promotorem „efektywnego multilateralizmu”" rem w tej kategorii będzie Organizacja Narodów Zjednoczonych. Tak się jednak nie

\footnotetext{
Lara Comi, PPE, IT, 2009.

83 Ana Maria Gomes, PSE, PT, 2008.

84 Emma Bonino, ALDE, IT, 2005.

85 Ioannis Varvitsiotis, PPE-DE, EL, 2008.

86 Georgios Toussas, GUE/NGL, EL, 2005.

87 S. Keukeleire, T. Delreux, The Foreign Policy of the European Union, s. 300.
} 
dzieje. ONZ jest co prawda wspominana przez deputowanych, ale nie w charakterze instytucji, której działania się kontestuje lub wobec której wysuwa się żądania. Pojawia się w debatach raczej jako pewnego rodzaju drogowskaz, wyznacznik polityki. Deputowani powołują się na dane ONZ, wskazują, w którym miejscu polityka jest niezgodna z niektórymi dokumentami czy raportami, ale samej działalności ONZ nie kontestują (poza jednym przypadkiem dotyczącym oenzetowskiego programu walki z narkotykami). Społeczność międzynarodowa jest zatem w wypowiedziach deputowanych tworem niesprecyzowanym i odnosi się do wszystkich aktorów zewnętrznych zaangażowanych w konflikt. Tylko jedna z wypowiedzi sugeruje, że pod tym pojęciem mogą kryć się także organizacje pozarządowe i humanitarne ${ }^{88}$.

\section{KORZYŚCI I KOSZTY}

Ostatnim etapem analizy tego, w jaki sposób europosłowie kontestują politykę UE względem Afganistanu, jest ocena przez nich korzyści i kosztów związanych z tą interwencją. Można je podzielić na kilka kategorii: koszty i korzyści osobowe i materialne dla Afganistanu i dla UE, zwiększenie/zmniejszenie bezpieczeństwa UE, wzrost/spadek znaczenia UE na arenie międzynarodowej. Częstotliwość występowania powyższych ocen przedstawia rysunek 2 .

Rysunek 2. Adresaci żądań politycznych a narodowość eurodeputowanych

\begin{tabular}{|c|c|c|c|c|c|c|c|c|c|c|c|c|}
\hline & $\stackrel{丶}{\not}$ & i & 岂 & $\vec{n}$ & 乌్థ & $\underline{\underline{\underline{\underline{ }}}}$ & 上 & 兰 & $\mathscr{w}$ & $\vec{a}$ & $\sqsupset$ & 뚠 \\
\hline operacja przynosi korzysci dla AFG & & & ० & & & & $\circ$ & 0 & & $\bullet$ & & \\
\hline operacja przynosi koszty dla AFG & & & ○ & & & $\bullet$ & & ○ & & & & O \\
\hline operacja przynosi koszty dla UE/MS & & $\bullet$ & $\circ$ & $\circ$ & $\bullet$ & ○ & $\bullet$ & & & 0 & & ○ \\
\hline operacja zwieksza bezpieczenstwo UE & & & & & & & & & & $\circ$ & $\bullet$ & \\
\hline operacja wzmacnia nas na arenie miedzynarodowej & & & & & & & - & & - & 0 & & \\
\hline
\end{tabular}

Źródło: opracowanie własne.

Uwagę zwracają dwie kwestie. Po pierwsze brak wypowiedzi świadczących o tym, że operacja przynosi jakiekolwiek korzyści materialno-osobowe dla Unii Europejskiej, a także o tym, że sytuacja bezpieczeństwa UE (czy to wewnętrznego, czy zewnętrznego) oraz jej status na arenie międzynarodowej pogarszają się ze względu na działalność w Afganistanie. Drugim łatwo zauważalnym zjawiskiem jest wzmożona kontestacja kosztów ponoszonych przez UE wyrażana przez brytyjskich deputowanych. Analizując ten swego rodzaju bilans zysków i strat, warto zaznaczyć, że w dotyczących go wypowiedziach słowem najistotniejszym według współczynnika TFIDF jest wyraz billion, co jednoznacznie wskazuje, jakie koszty eurodeputowani mieli głównie na myśli.

88 Marielle De Sarnez, ALDE, FR, 2010. 
Jak już wspomniano, najbardziej krytycznie bilans polityki UE czy szerzej - państw europejskich oceniają Brytyjczycy. To właśnie w ich wypowiedziach można znaleźć najwięcej odwołań do kosztów niematerialnych, czyli tych związanych ze śmiercią żołnierzy. Wystąpienia te są bardzo emocjonalne, często połączone w wymienianiem poległych z imienia i nazwiska ${ }^{89}$. W przypadku Wielkiej Brytanii nie dziwi taka postawa deputowanych, gdyż żołnierze brytyjscy byli obecni w Afganistanie w dużej liczbie i w dodatku w bardzo trudnym terenie. Deputowani z innych krajów członkowskich (np. Polski czy Francji) również wypowiadają się w podobnym tonie, choć dużo mniej intensywnie. Mówiąc o kosztach osobowych, deputowani nie ograniczają się tylko do wymieniania strat własnych. Należy zaznaczyć, że ofiary wśród afgańskiej ludności cywilnej są w wypowiedziach europosłów zauważane, ale nie mówi się już o nich z precyzją, rzadko podając konkretne liczby. Wypowiedzi o ewentualnych korzyściach dla Afganistanu wynikających z interwencji państw europejskich są sporadyczne, czasem wręcz nacechowane pewną dozą naiwności: Cieszę się, że UE nie odwraca się plecami do Afganistanu i że europejski podatnik funduje środki stużace promowaniu demokracji $w$ kraju, o którym Bóg i świat zapomniat [...]. Niezależnie od kosztów wierze, że udato nam się udzielić prawdziwej pomocy podczas ostatnich wyborów ${ }^{90}$.

Podczas debat pojawiło się też kilka głosów, jakoby polityka UE w Afganistanie sprawiała, że polepsza się sytuacja bezpieczeństwa w Europie, gdyż zapobiega ona napływowi tysięcy migrantów ${ }^{91}$ i ogranicza zagrożenie terrorystyczne ${ }^{92}$. Ponadto wedle niektórych wypowiedzi zaangażowanie w Afganistanie ma sprawić, że UE stanie się globalnym graczem na międzynarodowej arenie politycznej - tu po raz kolejny deputowany z Polski wiódł prym w takiej argumentacji: Jeśli UE ma ambicje stania się globalnym graczem, musi ze szczególnq uwaga ksztattować swoją politykę zagraniczna w regionach, które można określić jako „czarne dziury” na geopolitycznej mapie. Afganistan jest wtaśnie takim miejscem ${ }^{93}$.

\section{KONKLUZJE}

Pomimo dobrej pozycji Parlamentu Europejskiego, jeśli chodzi o mechanizmy i zdolności organizacyjne (authority oraz ability) umożliwiające kontrolę polityki bezpieczeństwa UE, w kwestii Afganistanu PE zdaje się nie wykorzystywać tych atutów z powodu braku większego zainteresowania kwestią Afganistanu. Świadczy o tym niewielka liczba debat poświęconych analizowanej tematyce. Jednym z możliwych wyjaśnień jest fakt, że zaangażowanie UE w Afganistanie cieszy się generalnym (choć, jak wykazano powyżej, oczywiście niebezkrytycznym) poparciem wśród większości frakcji politycznych w PE. Wywołuje tym samym mniej kontrowersji, przez co jest także rzadziej

\footnotetext{
89 Nick Griffin, NI, UK, 2010; Richard Howitt, S\&D, UK, 2009.

90 Ryszard Czarnecki, NI, PL, 2005.

91 Mirosław Piotrowski, ECR, PL, 2012.

92 Vytautas Landsbergis, PPE-DE, LT, 2005.

93 Mirosław Piotrowski, ECR, PL, 2012.
} 
debatowane ${ }^{94}$. Idąc jednak dalej tym tropem, zastanawia fakt, że nawet w momencie znacznego pogorszenia się sytuacji w Afganistanie i braku efektywności działań społeczności międzynarodowej, w tym UE, kwestia ta nie stawała się bardziej istotna, a po 2013 r. w ogóle zniknęła z agendy. Można się domyślać, że było to spowodowane ogólnym zmniejszeniem zainteresowania tym konfliktem związanym $\mathrm{z}$ wygaszaniem zaangażowania międzynarodowego z końcem $2014 \mathrm{r}$.

Jeżeli zaś chodzi o same żądania polityczne i charakter kontestacji polityki bezpieczeństwa UE w Afganistanie, to z pewnością pewnym paradoksem jest nacisk eurodeputowanych na wykorzystanie cywilnych środków w rozwiązywaniu tego kryzysu, a jednocześnie bardzo niewiele odwołań do misji EUPOL-A, która właśnie takie środki stosuje. Oczywiście EUPOL jest stosunkowo niewielką operacją, ale nawet w przypadku misji ISAF deputowani nie wypowiadają się zbyt obszernie na temat cywilnej strony tej operacji (brak np. jakichkolwiek wzmianek na temat PRT - Zespołów Odbudowy Prowincji, które miały stanowić trzon niekinetycznej kampanii NATO w Afganistanie).

Nie dziwi natomiast skoncentrowanie się eurodeputowanych na cywilnym podejściu do zaangażowania UE w ten konflikt oraz na konkretnych aspektach, takich jak prawa kobiet (czy szerzej prawa człowieka), wolność słowa etc. W tym przypadku wydaje się, że zarówno zainteresowanie (attitude), jak i zdolność organizacyjna i wiedza ekspercka (ability) Parlamentu Europejskiego plasują się na dużo wyższym poziomie. Nie można jednak na tej podstawie jednoznacznie stwierdzić, który z tych trzech czynników będzie najważniejszy, jeśli chodzi o intensywność kontestacji danego aspektu polityki bezpieczeństwa przez dane gremium parlamentarne. Każdy przypadek posiada osobny kontekst, który musi być brany pod uwagę przy analizie konkretnych studiów przypadku, niemniej, jak zauważa Ariella Huff, to właśnie zainteresowanie parlamentarzystów jest sine qua non odpowiedniej kontroli demokratycznej ${ }^{95}$.

\section{BIBLIOGRAFIA}

Born H., Hänggi H., The Use of Force under International Auspices. Strengthening Parliamentary Accountability, Geneva 2005, Policy Paper, 7.

Dahl R.A., A democratic dilemma. System effectiveness versus citizen participation, „Political Science Quarterly" 1994, Vol. 109, nr 1, [online] https://doi.org/10.2307/2151659.

Duchêne F., Europe's role in world peace, [w:] Europe Tomorrow. Sixteen Europeans Look Ahead, ed. R. Mayne, London 1972, Fontana, 2730.

European Parliament, Report on a new strategy for Afghanistan, 2009/2217(INI), [online] http:// www.europarl.europa.eu/sides/getDoc.do?pubRef=-//EP//NONSGML+REPORT+ A7-2010-0333+0+DOC+PDF+V0//EN\&language $=\mathrm{EN}$.

94 Zob. A. Huff, Problems and patterns in parliamentary scrutiny of the CFSP and CSDP, „OPAL Online Paper Series" 2013, Vol. 14, s. 18.

95 A. Huff, Executive privilege reaffirmed? Parliamentary scrutiny of the CFSP and CSDP, „Western European Politics" 2015, Vol. 38, nr 2, s. 411, [online] https://doi.org/10.1080/01402382.2014.990697. 
Handbook of Public Policy Analysis. Theory, Politics, and Methods, red. F. Fischer, G.J. Miller, M.S. Sidney, London 2006.

Hänggi H., The use offorce. Parliamentary accountability and „Democratic deficits”, [w:] H. Born, H. Hänggi, The „Double Democratic Deficit”. Parliamentary Accountability and the Use of Force Under International Auspices, Ashgate 2004.

Howorth J., Security and Defence Policy in the European Union, Basingstoke 2007.

Huff A., Executive privilege reaffirmed? Parliamentary scrutiny of the CFSP and CSDP, „Western European Politics" 2015, Vol. 38, nr 2, [online] https://doi.org/10.1080/01402382.2014. 990697.

Huff A., Problems and patterns in parliamentary scrutiny of the CFSP and CSDP, „OPAL Online Paper Series" 2013, Vol. 14.

Inigo-Mora I., Rhetorical strategies in the British and Spanish parliaments, [w:] European Parliaments under Scrutiny, ed. C. Ilie, Amsterdam 2010, Discourse Approaches to Politics, Society, and Culture, 38.

Interinstitutional Agreement of 20 November 2002 between the European Parliament and the Council concerning access by the European Parliament to sensitive information of the Council in the field of security and defence policy, 2002/C 298/01.

Keukeleire S., Delreux T., The Foreign Policy of the European Union, Basingstoke 2014.

Meyer C.O., Convergence towards a European strategic culture? A constructivist framework for explaining changing norms, „European Journal of International Relations” 2005, Vol. 11, nr 4, [online] https://doi.org/10.1177/1354066105057899.

Rosén G., EU confidential. The European Parliament's involvement in EU security and defence policy, „Journal of Common Market Studies” 2015, Vol. 53, nr 2, [online] https://doi. org/10.1111/jcms.12154.

Scharpf F.W., Governing in Europe. Effective and Democratic, Oxford 1999.

Schmidt V.A., Democracy and legitimacy in the European Union revisited output, input and throughput, „Political Studies” 2013, Vol. 61, nr 1, [online] https://doi.org/10.1111/ j.1467-9248.2012.00962.x.

Wagner W., The democratic control of military power Europe, „Journal of European Public Policy" 2006, Vol. 13, nr 2.

Wagner W., The democratic deficit in the EU's security and defense policy - why bother?, referat wygłoszony na EUSA Tenth Biennial International Conference Montreal, Canada, 17-19 V 2007.

Zielonka J., Europe's new civilizing missions. The EU's normative power discourse, „Journal of Political Ideologies” 2013, Vol. 18, nr 1, [online] https://doi.org/10.1080/13569317.2013.750172.

Marcin ZUBEK - magister europeistyki, doktorant w Instytucie Europeistyki UJ. Jego zainteresowania badawcze obejmują m.in. procesy pokojotwórcze oraz problem demokratycznej kontroli polityki bezpieczeństwa. Uczestnik seminariów i kursów na KU Leuven, Uniwersytecie Maastricht, Prague Security Studies Institute i Centre for Comparative Conflict Studies w Belgradzie. 